\title{
B
}

Instituto Federal de Brasília

Campus Brasília

Curso Licenciatura em Dança

Gisele Moraes Pereira

\section{IMPROVISAÇÃO COMO COREOGRAFIA?}


Gisele Moraes Pereira

\section{IMPROVISAÇÃO COMO COREOGRAFIA?}

Monografia apresentada ao curso de Licenciatura em Dança do Campus Brasília do Instituto Federal de Brasília, como Trabalho de Conclusão de Curso - TCC, aprovado como requisito parcial para obtenção do grau de Licenciada em Dança.

Orientadora: Prof. ${ }^{a}$ Dra. Raquel Purper. 


\title{
TERMO DE APROVAÇÃO
}

\author{
GISELE MORAES PEREIRA
}

\section{IMPROVISAÇÃO COMO COREOGRAFIA?}

\begin{abstract}
Monografia apresentada ao curso de Licenciatura em Dança do Campus Brasília do Instituto Federal de Brasília, como Trabalho de Conclusão de Curso - TCC, aprovado como requisito parcial para obtenção do grau de Licenciada em Dança.

Orientadora: Prof. a Dra. Raquel Purper.
\end{abstract}

Aprovado em 25 de junho de 2019

BANCA EXAMINADORA
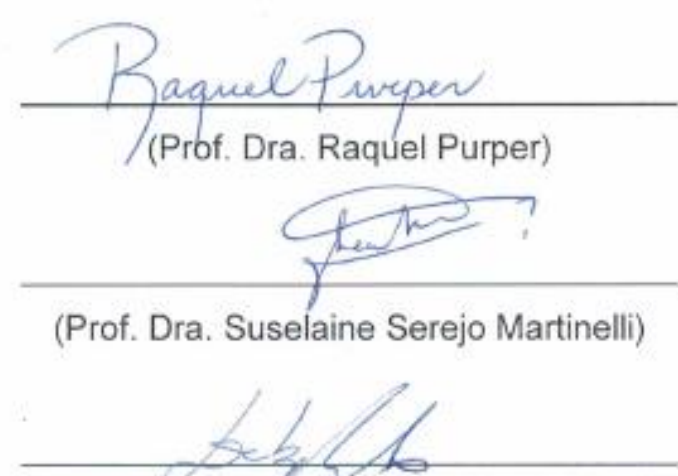

(Prof. Ms. Deborah Dodd Ferrez Alves de Macedo) 


\section{AGRADECIMENTOS}

A minha mãe e meu irmão por respeitarem minha escolha e me apoiar independente das circunstâncias.

Aos meus colegas do primeiro semestre, o acolhimento e o carinho de vocês foi fundamental nessa jornada.

A minha amiga Nathália (Taty), por ser presente em minha vida e me permitir ser presença na sua, pelo carinho, pelo apoio, por ser minha melhor companhia durante a graduação.

A minha amiga Kayrle, pelas conversas, pelo apoio, pelas várias ajudas e por me aguentar falando de dança o tempo inteiro.

Aos artistas que se disponibilizaram a realizar as entrevistas, em especial ao Pedro e ao Samuel que toparam a ideia desde o início, obrigada pelo suporte.

As Professoras Suse Martinelli e Deborah Dodd por aceitarem o convite para compor a banca avaliadora e serem parte importante dessa etapa.

A minha orientadora Raquel Purper, gratidão, pela disponibilidade sempre, pelo apoio, pela confiança, pelo incentivo, me sinto muito realizada em partilhar esse momento contigo. 
$O$ conhecimento, o reconhecimento e as associações acontecem pelo corpo.

Zilá Muniz 


\section{RESUMO}

Esta pesquisa visa compreender a composição coreográfica como produção artística que nasce da construção de experiências corpóreas buscando favorecer e potencializar o movimento improvisado como coreografia. Aborda elementos presentes na improvisação em dança e nas danças urbanas breaking e hip-hop freestyle apresentando experiências de artistas da dança com o intuito de agregar ao trabalho diferentes perspectivas e reflexões. Sua base metodológica é inspirada na pesquisa documental qualitativa enquanto caminho para a construção de conhecimento, sendo desenvolvida também a partir de uma análise reflexiva baseada em dados etnográficos concebidos por meio de entrevistas semiestruturadas. Discute sensivelmente acerca de conceitos como: pensamento contemporâneo em dança, coreografia, intérpretecriador, processos colaborativos, improvisação e suas relações. Com o intuito de contribuir com as reflexões sobre dança na contemporaneidade, apresenta caminhos e conhecimentos sob diferentes olhares evidenciando procedimentos na concepção e organização da criação em dança abordada pelo viés do movimento improvisado.

Palavras-chave: Coreografia. Improvisação. Intérpretecriador. Pensamento contemporâneo em dança. Processos colaborativos. 


\begin{abstract}
This research aims to understand the choreographic composition as artistic production that is born from the construction of body experiences seeking to favor and potentialize the improvised movement as choreography. It addresses elements present in improvisation in dance and urban hip hop freestyle and breaking dances presenting experiences of dance artists with the intention of adding to the work different perspectives and reflections. Its methodological base is inspired by qualitative documentary research to build knowledge. Being developed also from a reflexive analysis based on ethnographic data conceived through semi-structured interviews. Discusses sensibly about the concepts contemporary thinking in dance, choreography, interpretercreator, collaborative processes, improvisation and their relationships. In order to contribute to reflections of contemporary dance, presents paths and knowledge under different eyes evidencing procedures in the design and organization of dance creation tackled by the bias of the improvised movement.
\end{abstract}

Keywords: Choreography. Improvisation. Interpretercreator. Contemporary thinking in dance. Collaborative processes. 


\section{SUMÁRIO}

$\begin{array}{ll}\text { INTRODUÇÃOO } & 09\end{array}$

DESLOCAMENTOS DILATADOS

1. Pensamento Contemporâneo em Dança 13

CAMINHOS RIZOMÁTICOS

$\begin{array}{lr}\text { 2. Coreografia } & 17\end{array}$

2.1 Intérpretecriador e Processos colaborativos 20

2.2 Improvisação 22

CONFLUÊECIAS

3. Danças Urbanas: Breaking e Hip Hop Freestyle 27

$\begin{array}{lc}\text { 3.1 Musicalidade e Liberdade } & 30\end{array}$

LIAMES

4. Reflexões sobre a Improvisação como Coreografia 34

CONSIDERAÇÕES FINAIS

$\begin{array}{ll}\text { REFERÊNCIAS } & \mathbf{4 0}\end{array}$

ANEXOS 


\section{INTRODUÇÃO}

O presente estudo tem como objetivo compreender a coreografia como produção de experiências corpóreas, a qual transcende a reprodução de um código, buscando favorecer e potencializar o movimento improvisado como composição coreográfica. Por meio de elementos presentes na improvisação em dança e nas danças urbanas breaking e hip-hop freestyle, apresenta questões pertinentes ao fazer da dança, propiciando um espaço de reflexão sensível sobre essa forma de concepção do movimento dançado.

Para tal, reflete sensivelmente sobre os conceitos de pensamento contemporâneo em dança, coreografia, improvisação, processos colaborativos e os vínculos que esses possuem através de uma investigação teórica fundamentada em artigos, dissertações e teses. Por meio de entrevistas, associa experiências e conhecimentos de artistas pesquisadores a respeito da composição coreográfica com o intuito de agregar também diferentes olhares e considerações acerca do tema abordado.

A primeira prática de dança experimentada por mim, por poucos meses, foi a dança urbana breaking. Não consegui continuar com as aulas e, aos poucos, fui perdendo a conexão com os procedimentos experienciados. Ao retomar o contato efetivo com a dança, segui por outros caminhos, sendo apresentada a práticas de improvisação e da educação somática ${ }^{1}$. Após algum tempo, passei também a realizar aulas regulares de diferentes estilos de dança, seguindo os processos de cópia e reprodução.

Ao iniciar meus estudos em dança na licenciatura do IFB, me deparei com vários questionamentos e inúmeras possibilidades. A busca pela percepção dos movimentos internos, pelo conhecimento consciente da estrutura corporal e muitas de suas possibilidades, que ocorreram principalmente nos três primeiros semestres da graduação, provocaram em mim o desejo de construir uma relação mais orgânica com a dança. Desde então, as linhas de pesquisa que me despertaram o interesse foram a improvisação e os processos colaborativos.

O entendimento que desenvolvi por relação orgânica com a dança passa pelo referencial somático de atenção ao modo como agimos em relação ao nosso próprio corpo. Sempre ouvi colegas relatarem sentir dores musculares constantes ou possuírem lesões devido ao esforço

\footnotetext{
1 “A Educação Somática é um campo teórico-prático com diferentes métodos, onde o eixo de atuação é o movimento do corpo como via de prevenção ou de transformação de desequilíbrios de uma pessoa". (BOLSANELLO, Débora Pereira. Em Pleno Corpo: Educação Somática, Movimento e Saúde. $N^{\circ}$ 2. Editora Juruá, 2010, p. 18).
} 
repetitivo e, muitas vezes, excessivo que realizavam. Por isso, escolhi agregar também à minha prática procedimentos que propiciem a pesquisa em dança vinculada ao cuidado com o corpo, pelo movimento conscientizado.

Os trabalhos, nas componentes práticas nesse período inicial da graduação, eram feitos, em sua maioria, em grupos, nos quais todos eram instruídos a participar da construção das composições realizadas desde a reflexão sobre o tema da pesquisa (caso houvesse), a investigação corporal e a organização dos elementos pertinentes à criação. Desse modo, os processos se davam por colaboração, no qual cada um tinha autonomia para apresentar sugestões e participar de maneira efetiva na tomada de decisão sobre cada escolha feita.

Mais à frente, ao cursar as disciplinas específicas de composição coreográfica, pude experienciar de modo um pouco mais intenso a criação em dança através da exploração de diferentes procedimentos, trabalhando a improvisação por meio de estrutura, roteiro, perguntas, direcionamentos derivados de verbos de ação, da sensibilização da respiração, da percepção cinestésica e da memória. Também houve momentos de relação da improvisação com outras áreas do conhecimento, como a fotografia e a literatura.

Após ter contato com diferentes abordagens do movimento improvisado, foi crescendo a necessidade de me aprofundar cada vez mais nessa linha de pesquisa. O presente trabalho é parte do início da concretização dessa busca. Sendo a improvisação em dança um vasto campo de possibilidades, sua exploração será tratada, aqui, na relação com a composição coreográfica. Para auxiliar tal entendimento, serão apresentados também, relatos de artistas da dança a respeito de como estes compreendem os conceitos aqui abordados partindo de suas vivências.

A improvisação, muitas vezes, é utilizada em processos de criação como aquecimento, preparação corporal, prática de exploração do movimento e, posteriormente, acaba sendo descartada dando lugar à repetição de passos sequenciados. Nesses casos, é necessário ressaltar a importância de nomear o uso da improvisação em processos criativos para, assim, evidenciar essa forma de criação dentro dos muitos espaços onde a dança se faz presente e, introduzir o entendimento de improvisação como coreografia.

Desenvolvo a escrita do trabalho tratando, inicialmente, de referências conceituais a respeito dos termos: pensamento contemporâneo em dança, coreografia, intérpretecriador ${ }^{2}$, processos colaborativos e improvisação, dialogando com as autoras Alexandra Moojen e Raquel Purper (2014), Janaína Morais (2014), Marina Elias (2015), Mara Guerrero (2008),

\footnotetext{
${ }^{2}$ Nesta pesquisa utilizo o termo intérpretecriador por acreditar que estes dois conceitos estejam interligados na prática diária dos processos de pesquisa em dança, por isso a relevância em conectar as duas palavras também na forma escrita.
} 
Thembi Rosa Leste (2010), Vancleia Porath (2012), Zilá Muniz (2014), entre outros estudos que alimentam a pesquisa.

Em seguida, apresento reflexões do encontro entre elementos presentes na improvisação em dança e nas danças urbanas breaking e hip hop freestyle e seus desdobramentos abordando as autoras Flávia Vieira e Francine de Bom (2015) e também o coreógrafo e pesquisador Henrique Bianchini (2016). Por meio de entrevistas com artistas que atuam nessas áreas, acrescento ao longo do texto, dialogando com o referencial teórico, as experiências dos pesquisadores, coreógrafos, professores, Antonio Alves - TonTon (2018), Lucas Emanuel Rodrigues - Emanu (2018), Renato Fernandes (2019), Samuel Paniago (2018) e do intérpretecriador e pesquisador Pedro Ivo Saliba - Bisturi (2018).

No primeiro capítulo, abordo o pensamento contemporâneo em dança e sua importância para o entendimento da composição coreográfica como algo que vai além de sua compreensão pelo senso comum. Apresento, no segundo capítulo, questões relevantes a respeito da coreografia e do coreógrafo, do papel do bailarino e a emergência da figura do intérpretecriador bem como dos processos colaborativos e da improvisação. O terceiro capítulo trata de elementos presentes nas danças urbanas breaking e hip hop freestyle relacionando-as com o movimento improvisado. No quarto capítulo são apresentadas reflexões sobre a criação de dança e a improvisação como coreografia.

O estudo realizado tem sua base metodológica inspirada na pesquisa documental enquanto caminho para a construção de conhecimento crítico reflexivo. "Fazer pesquisa documental não é necessariamente promover uma investigação histórica do objeto. $\mathrm{O}$ método de pesquisa documental pode ser utilizado para abordar uma questão contemporânea" (SILVA et al., 2009, p. 4564). Para tal, estabelece uma relação qualitativa, demandando não apenas a coleta de dados, mas também a interpretação das informações apontadas através da seleção e análise de artigos, dissertações e teses sobre os conceitos investigados.

\footnotetext{
Na pesquisa documental, parte-se de um amplo e complexo conjunto de dados para se chegar a elementos manipuláveis em que as relações são estabelecidas e obtidas as conclusões. Os procedimentos [...] exigem a sensibilidade, a intencionalidade e a competência teórica do pesquisador, pois desde o acesso e a seleção do acervo documental, a análise dos dados até a comunicação dos resultados constitui-se um processo sistemático, exaustivo, coerente, sensível e criativo. (SILVA et al., 2009, p. 4561).
} 
Também desenvolvo uma análise reflexiva baseada na etnografia ${ }^{3}$, através da coleta de dados etnográficos concebidos por meio de entrevistas realizadas a partir de um questionário semiestruturado. Uma delas foi gravada em mp3 e transcrita posteriormente, e as demais tiveram as falas registradas em texto quando as perguntas foram sendo respondidas. Durante algumas entrevistas, outras perguntas consideradas relevantes para este estudo surgiram. As observações aqui apresentadas visam proporcionar diferentes percepções respeitando os pontos de vista de cada entrevistado.

Esta pesquisa tem sua importância justificada na necessidade de evidenciar e legitimar a compreensão da produção coreográfica como construção de uma experiência corpórea. A apresentação de caminhos, a partir de diferentes olhares e a interação entre fundamentos e técnicas distintas, mostra-se relevante para aqueles que atuam como intérpretescriadores. Articulando teoria e prática, entendendo-as como ambientes de produção de conhecimento, vislumbrei uma maneira de compreender a prática da improvisação como criação coreográfica.

\footnotetext{
3 "A etnografia é um método de pesquisa que considera a dimensão sociocultural do fenômeno estudado, caracterizando-se como uma atividade minuciosa e reflexiva de observação e descrição, a partir da imersão do pesquisador no seu campo de trabalho". (DANTAS, Mônica Fagundes. Ancoradas no corpo, ancoradas na experiência: etnografia, autoetnografia e estudos em dança. Urdimento, v. 2, n. 27, p.168-183, UDESC, 2016, p. 170 apud PATTON, 2002.)
} 


\section{DESLOCAMENTOS DILATADOS}

\section{1- Pensamento Contemporâneo em Dança}

Inicio o texto tomando emprestado de Agamben (2009) a seguinte indagação: O que é ser contemporâneo? Este é um conceito que tem sentido equivalente ao de tempo atual, de algo que é feito no presente, ser/viver no seu tempo. "A contemporaneidade, portanto, é uma singular relação com o próprio tempo, que adere a este e, ao mesmo tempo, dele toma distâncias" (AGAMBEN, 2009, p. 59). Ser contemporâneo é desenvolver uma percepção capaz de deslocar a atenção do próprio tempo e se conectar com os períodos anteriores refletindo os conhecimentos adquiridos:

\footnotetext{
O contemporâneo não é apenas aquele que, percebendo o escuro do presente, nele apreende a resoluta luz; é também aquele que, dividindo e interpolando o tempo, está à altura de transformá-lo e de colocá-lo em relação com os outros tempos, de nele ler de modo inédito a história ) de "citá-la" segundo uma necessidade que não provém de maneira nenhuma do seu arbítrio, mas de uma exigência à qual ele não pode responder. (AGAMBEN, 2009, p.72).
}

Cada período da história aborda uma maneira específica de pensar o corpo. Por ter se modificado ao longo do tempo, gerou consequências no pensamento sobre dança. Segundo Muniz (2014, p. 45) “O pensamento não é algo a ser buscado exclusivamente nas formulações teóricas da filosofia ou da ciência. Ele pode, sim, ser encontrado em cada modo de falar, fazer e conduzir a si mesmo". Tal abordagem caracteriza o pensamento contemporâneo, onde a importância da experiência se destaca.

As transformações ocorridas no entendimento sobre corpo ficam mais claras ao direcionarmos nosso olhar para alguns pontos dos períodos vividos, vale ressaltar que grande maioria dos estudos sobre esse assunto aborda um contexto histórico eurocêntrico. Conforme Langendonck (2008), podemos observar que, no início dos tempos, a relação do homem com seu corpo estava ligada ao sagrado, à natureza, aos rituais. Em determinado momento, passou a ser venerada uma presença disciplinada, incentivada pela igreja no sentido de manter a purificação. Tempos depois, essa visão foi dando lugar à necessidade de exibir um físico definido, valorizando o tônus muscular. Em um outro momento, o corpo deixa de ser visto como mero instrumento e passa a ser tratado como totalidade do ser.

Nesse sentido, o corpo abrange lugares do sensível, relacionando-se a questões do conhecimento sobre os processos desempenhados por este, gerando condições para uma construção de experiências crítico reflexivas. "Uma vez que 'eu sou o corpo', qualquer pensamento, plano, ideia, imagem ou memória estão situados no meu corpo e são originários 
do meu corpo" (MUNIZ, 2014, p. 114). As mudanças sobre o entendimento de corpo influenciaram as estratégias utilizadas para produzir coreografia, pois é no corpo que a dança acontece - o movimento parte do próprio ser. Sendo assim, ao longo do tempo, cada vez em que a maneira de se relacionar com o corpo ganha uma perspectiva diferente, devido ao momento vivenciado, a dança criada é diretamente afetada por este.

Segundo Langendonck (2008), em seu percurso pelo tempo, a dança se relaciona com diferentes contextos referentes a cada momento histórico vivenciado, tendo assim contribuído nos modos como eram realizadas a criação e apresentação das obras. As primeiras notações registradas revelavam um conjunto de movimentos que ilustravam como a dança deveria acontecer. Existia uma ideia fixada e, a partir dela, desenvolveu-se uma noção a respeito do que era dança: esse entendimento foi sendo reproduzido por um longo período, caracterizando-se como padrão, reconhecido como balé clássico.

A insatisfação de alguns artistas em relação a esse sistema impulsionou a elaboração de outros princípios para produzir e organizar dança. Ainda que negasse noções pontuais do pensamento vigente naquele momento, haviam elementos que continuavam sendo reforçados. Criou-se uma técnica que era vista como menos rígida que a anterior, a dança moderna, que buscava uma associação com a realidade vivida, porém ainda imprimia certa resistência e imposição em relação ao conhecimento e habilidades indispensáveis para atuar como criador e também como intérprete. (LANGENDONCK, 2008).

Durante o período da dança moderna, surgiram muitos questionamentos e diversas pesquisas passaram a ser desenvolvidas. O conceito de dança foi mais uma vez revisto e, consequentemente, a compreensão acerca deste se transformou. Houve abertura para uma concepção significativa que nasce do próprio corpo, "os movimentos articulados para atingir este posicionamento eram realmente nada mais que movimentos corporais, sem tratamento técnico em princípio. Os corpos foram despojados de todos os artifícios que os tornavam corpos idealizados" (MUNIZ, 2014, p. 86).

Ainda segundo Muniz (2014), a dança pós-moderna americana se amplia a partir do desejo de experimentar possibilidades do movimento em relação com o espaço, transforma as estruturas de composição coreográfica potencializando os processos de hibridismo entre as diversas linguagens artísticas. Estas ações foram de fundamental importância para o surgimento de uma outra compreensão sobre o conceito de dança e inspirou diversos artistas a introduzir e consolidar o que viria a ser a dança contemporânea.

Nessa abordagem, a dança se faz pelo interesse em ultrapassar a simples repetição de passos sistematizados e buscar uma construção de sentido, onde o movimento se associa a 
experiência abrangendo a conscientização e a sensibilização por meio da exploração de diversos estudos do corpo. (MUNIZ, 2014). A dança integra o pensamento contemporâneo em seus processos pela construção de conhecimento através da teoria efetivamente ligada à prática artística, gerando um olhar crítico reflexivo no que diz respeito à composição coreográfica.

Algumas características indicam as transformações ocorridas na concepção de coreografia em cada contexto. No balé clássico, esta se dava pelo maítre que era o principal coreógrafo de uma companhia. Ele criava os repertórios, conjunto de coreografias que contavam uma história, a dança deveria expressar as emoções da narrativa que estava sendo apresentada. Na dança moderna, o coreógrafo se mantinha como detentor do conhecimento e as composições eram baseadas em técnicas específicas de cada criador, tendo seus movimentos associados a um significado ou sentimento (LANGENDONCK, 2008).

No período da dança pós-moderna americana, o movimento por si só passa a ter grande destaque, as composições têm como princípio procedimentos distintos, entre eles o uso de ações cotidianas e jogos como ferramentas de criação. Também nesse momento, a inserção da improvisação nas obras passa a ter uma maior notoriedade, conquistando espaço para que o processo viesse a ser compreendido como parte fundamental da pesquisa coreográfica e não só o produto final a ser apresentado. (MUNIZ, 2014).

\footnotetext{
Não há problema algum em a dança ser um produto artístico: um espetáculo, uma apresentação. Entretanto o processo da criação do produto de dança é muito importante, pois nele temos a produção de conhecimento. Ou seja, criamos questionamentos, os solucionamos, discutirmos o que estamos fazendo, narramos, descrevemos, analisamos [...] propomos um modo de questionar o mundo, de refletir, de criticar, de concordar, de inventar um mundo. Tudo isso com a dança. (RENGEL et al, 2016, p.09)
}

Muitas questões foram afetadas de diferentes maneiras em momentos distintos, entre elas a relação da dança com a música. Conforme apontado por Rengel et al. (2016, p. 16) “A maioria das colaborações da música em eventos de dança tem finalidades claras: a música organiza a temporalidade, a sequência dos passos e movimentos, o enredo (no caso das danças narrativas, como o balé, por exemplo), o desenvolvimento da coreografia, o andamento". Nesse sentido, a música representa um papel fundamental na composição coreográfica.

Como consequência das transformações ocorridas nessa instância, som ambiente, percussão corporal, objetos usados como instrumentos musicais e até mesmo o silêncio foram sendo introduzidos e validados como potentes recursos a serem abordados na criação e na apresentação da dança. "Esse foi um momento de transformação e de ruptura, com propagação e ressonância intensas no mundo das artes e que historicamente definiu percursos que outras gerações ainda percorreriam" (MUNIZ, 2014, p. 66). 
Apesar de, no cenário internacional, a improvisação já ser validada, considero interessante ressaltar, aqui nessa pesquisa, a compreensão da improvisação como coreografia pelo viés do pensamento contemporâneo em dança, por este nos propiciar a reflexão sobre a dança que criamos e sobre os procedimentos empregados nesse fazer. "A falta de familiaridade com estes movimentos ressoam ainda hoje em preconceitos vigentes [...] [e] não pode ser desculpa para que a produção em dança brasileira [...] continue alheia aos processos de criações e configurações mais difundidos em outros contextos" (LESTE, 2010, p. 61).

Houve, por um longo tempo, a convicção de que, para criar dança, existe um caminho quase que universal a fim de alcançar um resultado satisfatório. A cada novo procedimento inserido nas técnicas de composição, percebe-se que inúmeras são as possibilidades a serem exploradas na concepção de coreografias. Os diferentes modos de produção da dança são difundidos e repercutidos nos mais variados âmbitos, sendo assim relevante refletir a respeito de como ocorrem tais ações.

Diversos pesquisadores e praticantes da dança abordam em seus locais de atuação os conhecimentos adquiridos dentro desse universo, e esses são de alguma forma reforçados por aqueles que compartilham dessa experiência. "Não necessariamente tudo o que você coloca na dança ou nos movimentos da sua aula é de modo consciente, mas conscientemente ou não, está expondo suas atitudes, tanto físicas quanto simbólicas diante da vida, da arte" (RENGEL et al, 2016, p.09). Por isso, percebo a importância de evidenciar a coreografia como uma construção de sentido para além da reprodução de passos sequenciados. 


\section{CAMINHOS RIZOMÁTICOS ${ }^{4}$}

\section{2 - Coreografia}

Segundo Caldas (2017, p. 29) “o termo coreografia é composto por: COREOGRÁFICO: o nome é autoexplicativo: ‘coreo', dança, 'gráfico', escrita ou desenho”. Tal termo é tratado pelo senso comum como uma sequência de passos dançados seguindo a música, com um "desenho" predefinido. Esse modo de ver e entender coreografia vêm sendo ressignificado e transformado de diversas maneiras ao longo do tempo, alterando as abordagens utilizadas para gerar dança. Nepomuceno (2014) nos lembra que:

De acordo com Trindade, inicialmente o termo coreografia era utilizado para
denominar apenas o ato de escrever as danças, ou seja, a notação coreográfica [...]
Não se sabe ao certo quando o termo que deveria nomear a ação de escrever a dança
acabou por definir também a ação criativa [...] a história não é linear, os eventos são
rizomáticos, provavelmente muitas foram as causas que levaram os dançarinos e
outros agentes relacionados ao cotidiano da arte de dançar a utilizar o termo
coreografia como sinônimo de daça e de criação em dança, alterando o sentido inicial
dessa palavra. (NEPOMUCENO, 2014, págs. 139 - 142).

Outros registros indicam mudanças ocorridas em relação aos conhecimentos entendidos como essenciais para criar coreografia. No final da década de cinquenta, o livro "A arte de criar danças" é lançado pela coreógrafa Doris Humphrey, um forte nome da dança moderna americana. Paixão (2003) afirma que Humphrey "sintetiza um pensamento comum entre os artistas de sua época elaborando um manual pedagógico para os criadores de danças (coreógrafos) focalizando a escolha das linhas eficazes, o desenho correto, a qualidade de reconhecer imagens para uma composição harmoniosa" (s.p.).

A coreografia foi, por um longo período, tratada apenas como uma construção de passos de um determinado código, um padrão a ser reproduzido e treinado pela repetição dos movimentos para assim chegar a um resultado refinado, na maioria das vezes supervalorizando as formas e sua execução de modo sincronizado. Conforme as pesquisas na área da criação em dança foram crescendo e se propagando, outros jeitos de olhar para o movimento foram surgindo e conquistando espaço:

\footnotetext{
4 "Deleuze e Guattari (2004) sugerem [...] o conceito de rizoma, a partir do qual não se busca fixar pontos, mas correr linhas. Essas linhas compõem um plano de consistência e por si só subvertem noções polarizadoras sobre corpo, sujeito e identidade. Ao oferecer a imagem do rizoma, que é um tipo de raiz sem eixos centrais encontrada, por exemplo, em gramíneas e nas samambaias, diferentemente das raízes axiais e pivotantes, que são centrais em relação às outras partes da planta, os autores acima promovem uma descentralização de poder, dando passagem ao pensamento da multiplicidade [...] Pensar em multiplicidade é pensar em possibilidades". (PIZARRO, Diego. Corpo, Interdisciplinaridade e Contato Improvisação. In: II Seminário e Mostra Nacional de Dança-Teatro Viçosa/MG, 2010, p. 05).
} 
A explosão da dança nos anos 60 esteve principalmente relacionada ao questionamento do corpo, da visibilidade, dos padrões e programas estabelecidos, e, acima de tudo, da interconexão sem precedentes entre as áreas artísticas. Interessa o corpo no tempo presente, à percepção dos fluidos, órgãos, pensamentos, os processos e procedimentos de criação que conscientemente rompem com estruturas estabelecidas. São nestas circunstâncias que as danças embasadas por princípios organizativos vem se instaurando. (LESTE, 2010, p. 32).

O intuito da presente pesquisa não é trazer um panorama sobre a evolução da coreografia na história da dança, e sim, apresentar aspectos relevantes para propiciar caminhos nos quais a coreografia possa também ser compreendida como construção de uma experiência corpórea que transcende a reprodução de um código, uma perspectiva que vem se legitimando na dança na contemporaneidade. "Num processo contemporâneo de criação em dança, é possível trabalhar com a ideia de coreografia, entendendo que a coreografia acontece em um percurso no qual a troca entre os participantes irá gerar uma materialidade criativa" (MOOJEN; PURPER, 2014, p. 124,125).

Para diferentes coreógrafos, o movimento por ele mesmo é o principal ponto de partida para a criação em dança. Cabe aqui ressaltar que ele acontece em uma constante relação entre as experiências vivenciadas pelo indivíduo e as transformações ao ser afetado por elas. Coreografia também se faz pela conexão de diferentes aspectos que possibilitam sua construção, que vai além da junção de passos. Vários elementos estão presentes nesse processo: as dinâmicas de tempo, a maneira como se utiliza o espaço, corpos conscientizados de suas potencialidades e disponíveis, a escuta, as escolhas feitas a partir daquilo que motiva a criação. Para o coreógrafo e pesquisador Renato Fernandes (2019),

Coreografia é o conjunto de códigos estéticos desenvolvidos por meio de alguma técnica pautada ou não, o montante de vivências e desenvolvimentos motores numa cadência sequenciada, guiados por alguma ordem estabelecida, com o objetivo de gerar algum símbolo, significado, visualidade e também desenvolvimento físico, habilidades e expressão corporal. (FERNANDES, 2019).

Diversos artistas pesquisadores da dança, ao tratarem da concepção de suas obras, passaram a adotar a terminologia "composição coreográfica". Tal acontecimento se deu pela dança apresentada não ser reconhecida como coreografia pelo senso comum devido a compreensão que se estabeleceu sobre o termo de forma sociocultural. Uma referência de criação muito reconhecida nesse sentido é a abordagem da composição coreográfica pautada na articulação e contextualização de um pensamento no corpo, de maneira a provocar questionamentos e a reflexão através do movimento dançado.

Paixão (2003) afirma que coreografia na contemporaneidade “[...] pode ser entendida como a estrutura de conexões entre diferentes estados corporais que figuram em uma dança e dela faz emergir seus nexos de sentidos” (s.p.). Compor em dança é trabalhar pela escuta sensível, 
selecionar material e organizá-lo numa síntese, sabendo-se que toda a pesquisa corporal nos apresenta inúmeras possibilidades e que optamos pelas que nos envolvem e de alguma forma nos direcionam para a poética que buscamos abordar. Ainda que haja uma vasta rede de perspectivas a respeito do conceito de coreografia, percebem-se noções similares entre profissionais de diferentes vertentes da dança, como observa o coreógrafo e pesquisador Antonio Alves - TonTon (2018):

\begin{abstract}
Uma coreografia, tem a ver com uma lógica pré existente, ela não precisa ser necessariamente engessada, não precisa ser algo pré montado, mas ela é uma ideia que pré existe e que pode ser repetida quantas vezes for necessário, a ideia, não necessariamente os movimentos, mas aquela ideia que vai em conjunto com alguma forma de representar aquilo. Então você pode dançar a mesma coreografia e ela ter várias caras diferentes, mas ainda assim é uma coreografia porque ela pré existe em conceito do que você quer. Então é algo que é estruturado, tem pensamento envolvido com aquilo. E lógico a gente tem as formas clássicas de coreografia que você tem uma sequência de movimentos que é a forma mais comum que as pessoas trabalham, mas eu acredito que você pode fazer uma sequência de ideias que vão aparecer ali e você vai passar isso vinte vezes e vão ser vinte vezes diferentes e ainda assim é uma coreografia. (TONTON, 2018).
\end{abstract}

Ao falar de coreografia, surge uma questão a ser tratada em processos de criação: a figura da pessoa que conduz. O coreógrafo(a) é quem possui a responsabilidade de criar a sequência coreográfica e ensiná-la pela prática da repetição. Existe a possibilidade dessa função ser exercida também pelo diretor(a) ocorrendo por meio de direcionamentos pertinentes a composição ou pela elaboração de um roteiro.

Em alguns casos, o coreógrafo elabora, organiza e registra sequências de movimentos a serem realizadas pelos bailarinos ${ }^{5}$. É tido como a figura central de um grupo ou companhia de dança, sendo comum apresentar características em sua maneira de mover e criar que se destacam gerando uma identidade reconhecida e, consequentemente, visível nos corpos de quem dança suas composições. Conforme os processos de concepção de dança foram se reinventando, as formas como o coreógrafo conduz suas atribuições e procedimentos se modificaram:

Como o coreógrafo vive um processo de criação, há em seu desempenho uma mistura entre elementos de ordem linguística e outros de outras tantas naturezas: sensação, história, memória, hábito, ritmo, som, relações cotidianas, paisagens, imagens, cultura, formação, etc. E há o quanto o efeito da performance do corpo que cria e o sentido que ela produzirá dependem do cruzamento dessas coisas todas, que são de naturezas diversas. (MUNIZ, 2014, p. 148).

Outro ponto relevante é como se dá a relação entre os bailarinos e o papel que desempenham na composição coreográfica. Geralmente, se espera que estes reproduzam

\footnotetext{
${ }^{5}$ Utilizo o termo bailarino na construção de alguns trechos da pesquisa por se tratar de uma referência ao modo como o intérprete é geralmente reconhecido nos diversos contextos da dança e quando, nesses trechos, falo de um coreógrafo que cria passos para serem copiados. Quem copia é o bailarino, e não o intérpretecriador - termo que defendo nesta pesquisa.
} 
determinada movimentação empregando elementos singulares do seu modo de dançar ou que evidenciem um código específico. A participação do bailarino na criação da composição está se tornando cada vez mais recorrente, principalmente quando as propostas envolvem a improvisação na investigação do movimento.

Nesse sentido, abrem-se espaços para relações não hierárquicas na elaboração e desenvolvimento de obras coreográficas. Em virtude do desenvolvimento dessa relação não hierárquica, emprega-se uma outra nomenclatura: a de intérpretecriador, sobre a qual falarei mais a frente. Com a introdução e a exploração de estratégias decorrentes do movimento improvisado, o coreógrafo passa a ocupar uma posição menos rígida e autoritária, mais como orientador, abrindo possibilidades de colaboração, passando a experienciar de outro modo a criação:

[...] torna[ndo]-se sensível ao processo a partir dos caminhos sugeridos pelos protocolos criados permitindo que a propriedade da obra seja disseminada reafirmando mais uma vez a existência das co-autorias no diálogo intenso entre os intérpretes-criadores e os coreógrafos/regentes de cena/diretores. (FERREIRA, 2012, p. 9).

\section{1 - Intérpretecriador e processos colaborativos}

O papel do bailarino foi ganhando novas perspectivas ao longo da história da dança. Este que, inicialmente, era treinado para interpretar coreografias de modo que a execução técnica e a expressão virtuosa fossem excelentes, aos poucos foi conquistando espaços de participação efetiva na criação. É através do bailarino que a obra encontra o público, que o afeta e gera reflexões. Ao colaborar como pesquisador do movimento, ou seja, ao atuar como intérpretecriador, tem-se um contato mais aprofundado e consciente com sua estrutura corporal, o que reflete diretamente na sua dança.

Muitos questionamentos são levantados a respeito da formação do intérpretecriador, termo que se legitimou no campo da dança contemporânea. Um lugar de reconhecimento das potencialidades do bailarino, da relevância do seu papel, que lhe apresenta novas perspectivas enquanto agente e carrega também muitas responsabilidades, a começar pela construção e desenvolvimento de um vocabulário próprio e de um repertório que lhe dê suporte significativo para a criação:

O termo "intérprete criador" tem sido utilizado no contexto da dança contemporânea e é um fenômeno que aparece, principalmente, a partir da década de 1990. De acordo com Dantas (2005), a cena contemporânea na dança derrubou fronteiras entre os campos artísticos com espetáculos, [...] mesclando elementos do teatro, da performance, do cinema, da música e das artes visuais. Da mesma forma, esses trabalhos trazem referências técnicas e criativas de outros campos representacionais, 
como o tradicional, o moderno, o popular, o folclórico e a cultura de massa. (MUNIZ, 2014, p. 91).

A interrelação entre diversas áreas proposta pela contemporaneidade possibilita experiências nas mais distintas práticas e técnicas corporais. Considero importante experimentar conhecimentos variados, desde que se tenha clareza de onde se quer chegar, e não simplesmente se deixar levar pela corrente do intenso fluxo de informações que isso pode causar. Por mais extasiante que seja vivenciar de tudo um pouco, é interessante que haja espaço para direcionarmos tempo para um trabalho sem tanta pressa, através da investigação profunda do movimento de maneira consciente.

Atuar como intérpretecriador demanda experiência, autoconhecimento, entendimento das práticas realizadas e da movimentação desenvolvida. Os trabalhos realizados por intérpretescriadores podem se dar de maneira em que a obra seja concebida puramente por estes e também em parceria com outros artistas. A prática com processos colaborativos viabiliza caminhos que nos incentivam a olharmos para os lugares em que nos colocamos enquanto pesquisadores e criadores de/em dança, o que nos leva a transmitir tais entendimentos nos mais variados espaços.

Em seus estudos sobre processos colaborativos, Moraes (2014, p. 28) ressalta a importância de percebermos "[...] colaboração como a possibilidade de, individualmente, tomar decisões no coletivo a partir de suas singularidades [...] não colaboração com todo mundo, o tempo todo, tendo que fazer de tudo com o mesmo grau de participação". A composição coreográfica, desenvolvida a partir dos procedimentos apresentados nesta pesquisa, está atrelada à compreensão de como me posiciono enquanto coreógrafa bem como intérpretecriadora:

\footnotetext{
Aquele que dança não mais tem a Dança, mas é a própria porque torna-se disponível para o processo de criação dentro de uma parceria entre aquele que propõe o trabalho (coreógrafo, diretor, regente de cena) e aqueles que propõem caminhos (coreógrafo/diretor/regente de cena e intérprete-criadores). (FERREIRA, 2012, p. 6).
}

Percebi, ao participar de alguns trabalhos de composição coreográfica durante a graduação, que, no desenvolvimento das investigações práticas, o material surgido ao colaborar como intérpretecriadora me instigou a exercer um olhar atento aos direcionamentos propostos para a improvisação. No lugar de coreógrafa, esse olhar estendeu-se para o modo como são abordados os procedimentos. As orientações são responsáveis pela intenção que queremos dar a dança que está sendo criada, nelas moram elementos permeados pelo pensamento que motiva a pesquisa.

A colaboração proporciona que os recursos utilizados por cada intérpretecriador e as referências que este escolhe agregar ao trabalho se transformem ao se integrarem com outros 
fatores já atribuídos à exploração do movimento, gerando uma confluência. A liberdade de seguir os impulsos que se revelam através dos estímulos do próprio corpo é somada aos momentos de registro das informações obtidas, das conexões concebidas, da seleção do que continuará a ser produzido:

\footnotetext{
O processo colaborativo, na dança, acontece a partir da utilização da improvisação como ferramenta de composição. Por meio da possibilidade de um corpo que improvisa [...] torna-se mais apto e capaz, um corpo criativo, emancipado no processo de diversificação, que abre a probabilidade de que criadores trabalhem com o bailarino improvisador sem negligenciar seu papel criativo. (MUNIZ, 2014, p. 29).
}

A escuta é um fator importante na criação colaborativa, dar atenção aos desdobramentos ocorridos, perceber o que o movimento provoca, estar disponível para o que nasce além das expectativas existentes, “[...] são escutas da ordem de uma valorização dos afetos produzidos pelo encontro de pensamentos singulares, que ao comporem juntos geram coreografias" (PORATH, 2012, p. 67). Uma mescla entre as ações do intérpretecriador durante a improvisação e das observações e reflexões de quem coreografa:

O fato de, enquanto diretora-coreógrafa, tomar decisões não diminui o teor coautoral e colaborativo do processo, já que as direções tomadas são resultados de rumos chegados pelo grupo como um todo, numa troca constante de estímulos, conversas, danças, improvisações e escolhas. (PORATH, 2012, p. 129).

Ao desenvolver uma pesquisa de movimento através de um processo colaborativo com intérpretescriadores, é recorrente lidar mais com questões do que com respostas em relação à composição coreográfica. As perguntas podem estar presentes em momentos distintos e se tornarem um recurso de criação. A partir delas, ocorrem improvisações, nascem estruturas, caminhos se organizam, sentidos são construídos e consolidados.

\section{2 - Improvisação}

Em sua origem, "a palavra Improviso deriva do latim IN PROMPTU, em estado de atenção, pronto para agir, que vem de IN, em, mais PROMPTUS, prontidão que, por sua vez, origina-se de PROMERE, fazer surgir" (SANTINHO; OLIVEIRA, 2013, p. 10). Entendo a improvisação em dança como uma pesquisa de movimento que busca transformar e/ou ressignificar ações já conhecidas e que possibilita a descoberta de outros modos de mover-se e 
alcançar estados de cinestesia ${ }^{6}$ mais conscientes, de maior apropriação do movimento. Embora alcance maior visibilidade na contemporaneidade,

\begin{abstract}
fazeres em dança que se dão através de processos de improvisação, ainda são alvos de olhares "duvidosos", descrenças com relação a seriedade das práticas e dos próprios materiais que estes podem gerar, tal desconfiança é também fruto das parcas informações acerca do termo improvisação e dos seus mais diversos modos de aplicação, entendimento e criação. (PORATH, 2012, p. 166).
\end{abstract}

Nesta pesquisa, a exploração da ideia de improvisação se associa também a elementos presentes nas danças urbanas breaking e hip hop freestyle, resultando em uma análise sobre a composição coreográfica nessas vertentes. Para tal, busquei explorar minhas referências no assunto, obtidas durante a graduação em dança, devido também ao contato com professores artistas que criavam composições através da improvisação e com outros pesquisadores ao participar de oficinas e residências, e também por meio de entrevistas realizadas com coreógrafos e pesquisadores.

A preparação do corpo que improvisa reflete no desenvolvimento das práticas realizadas durante os laboratórios e apresenta particularidades intrínsecas à poética presente nas escolhas feitas, influenciando a composição por completo. Tendo a improvisação como uma abordagem que viabiliza a exploração de distintas possibilidades de movimento, é interessante ressaltar sua potência enquanto facilitadora do autoconhecimento, este que na dança pode nos levar ao encontro com a sensação de cinestesia, um estado de entrega, escuta e percepção que torna mais rico o ato de improvisar.

$\mathrm{Na}$ improvisação em dança, estar em experiência de improvisação é se colocar em pesquisa, mantendo a atenção e a percepção ampliadas para agir de maneira a estabelecer relação com o outro e com o ambiente, relacionando com seu entorno e transformando essa experiência em material cênico. (SILVA; RAMOS, 2015, p.142).

Acredito que, quanto maior consciência de si o improvisador possuir, mais variações dos elementos explorados podem surgir e vir a serem agregados à construção da sua dança. A autora e pesquisadora Marina Elias (2015, p. 180) alega que "É através deste conhecimento de si, que conduz a um certo 'modo' de improvisar, que o improvisador abrirá a possibilidade de surpreender, a si e aos outros, pois é só constituindo uma estrutura que será possível romper com ela".

Esse conhecimento de si não se trata apenas de uma busca aprofundada da sensibilização da musculatura e dos conhecimentos referentes aos estudos do corpo humano, mas também de contextualizar tal prática relacionando-a com elementos que constituem a dança e o artista da

\footnotetext{
6 "Cinestesia: Conjunto de sensações pelas quais são percebidos os movimentos musculares cujos estímulos provêm do próprio organismo". (SANTINHO, Gabriela di Nonato Salvador; OLIVEIRA, Kamilla Mesquita. Improvisação em dança. Guarapuava: UNICENTRO, 2013, p. 26).
} 
cena, na qual os limites dicotômicos desapareçam e o improvisador se permita ser afetado pelo espaço, pelo tempo, pelo movimento, num transpassar contínuo:

Suas ideias e escolhas se tornam mais fluidas, em uma via de mão dupla na qual ele faz, mas também se deixa fazer, improvisa, mas também se deixa improvisar: um improvisador que não só compõe a cena, mas também se decompõe nela [...] Um improvisador que não é um ser da representação ou da intenção, mas um ser de intensidades. Um improvisador que sente, percebe, mas também faz sentir, faz perceber. (ELIAS, 2015, p. 175).

Tendo essa relação de estados permeados pela experiência como fator que à alimenta, a composição pela improvisação se dá no encontro de elementos que se relacionam e se transformam por influência do contexto vivenciado. Durante a investigação, é fundamental não ansiar por um resultado final e sim se entregar ao processo, permitindo-se experienciar o momento presente, estando atento e consciente às mudanças que ocorrem no vínculo movimento-espaço-tempo. As ações que nascem e quais qualidades possuem, aos caminhos que emergem no espaço, as predisposições temporais, um material sensibilizado a ser estruturado.

A improvisação foi introduzida por Émile Jaques-Dalcroze e Rudolf Laban na Dança Criativa na Europa, e por Margareth O’Doubler e Anna Halprin nos Estados Unidos. É um termo que abriga diversas manifestações e que não define uma única prática. A Improvisação, como é hoje utilizada, foi se sistematizando a partir do século XX e adquiriu um novo caráter quando foi incorporada pelos artistas do movimento pós moderno americano. Inicialmente como forma de experimentação. (MUNIZ, 2014, p. 24).

A improvisação nos conecta às nossas referências. As escolhas realizadas durante a exploração de movimentos estão associadas também às nossas experiências de vida, que nos tornam quem somos. A nossa maneira particular de dançar se constrói não só através de aulas de algum código específico ou de estudos desenvolvidos ao ter contato com diferentes práticas corporais. Ela carrega também vestígios do que nos afeta ao ler um livro, ver um filme, ouvir música, comer nossa comida favorita, olhar no olho de quem se gosta:

A improvisação trata-se de um conjunto de informações, psicomotoras desenvolvidas pelo intérprete em sua pesquisa de movimento, sendo ela guiada, livre ou roteirizada. O improvisador em geral, procura desenvolver linearidade em sua movimentação, buscando códigos e similaridades recorrentes em seu campo de vivências, em outros casos buscando exatamente o oposto: investigando locais incomuns, passeando ou não por diversas técnicas e também sendo levado pela atmosfera do ambiente em que se desenvolve a prática, podendo esses componentes serem externos: como a música, outros corpos, ou internos: como estímulos, memória, sentimentos e desejos. (FERNANDES, 2019).

A memória corporal se faz presente durante a prática da improvisação, podendo suscitar imagens, cores, cheiros, sensações pelas quais geramos movimento que ao ser experimentado profundamente abre possibilidades para outros movimentos surgirem. Tais particularidades conduzem quem improvisa a uma poética corporal singular. "Hoje a improvisação é um meio 
de agregar as diferenças, trazendo para a cena o dançarino com tudo o que ele é, e também o seu jeito de dançar” (MUNIZ, 2004, p.59).

Compor tendo um olhar para o intérprete abraçando suas singularidades requer, de quem se encontra como mediador do processo, abertura para o outro, bem como aquele mesmo conhecimento de si citado anteriormente. Tais características estão relacionadas ao seu entendimento sobre o corpo na dança e também nos processos de criação. Escolhi a improvisação para guiar essa pesquisa por ter sido sensibilizada através dessa prática a me relacionar de maneira mais orgânica com o movimento e com a criação em dança.

Nessa investigação, a improvisação torna-se um valoroso procedimento no desenvolvimento de um corpo criador, onde a emergência em aplicar as referências que possuímos sob uma outra perspectiva se estabelece através da relação entre a reflexão e o sensível. "A improvisação unifica o papel de criador e intérprete em cada pessoa, permitindo que o indivíduo tome decisões sobre a obra e observe a si próprio em ação" (MUNIZ, 2004, p.31).

A partir das investigações são acionados estados corporais que propiciam um ambiente para o desenvolvimento de uma poética para a composição. Improvisar requer um ser/corpo disponível, não se trata de uma inspiração que surge em determinado momento e nos faz criar. É um trabalho constante transformador da nossa maneira de mover a cada nova experimentação, ampliando vocabulário e dilatando referências:

[...] demanda estudo, treinamento e comprometimento; demanda uma abertura da sensibilidade para o estabelecimento de relação com o outro e com o entorno que circunda a experiência; demanda a ampliação da percepção para a tomada de decisão com propriedade sobre o que se faz e como se faz. (SILVA; RAMOS, 2015, p. 144).

Tendo a improvisação como caminho de pesquisa, consequentemente o intérpretecriador se coloca num lugar, no qual, de fato, possui autonomia dentro do processo vivenciado. É comum ouvir que improvisar é ser simplesmente espontâneo. Entendo ser relevante ter consciência de que poder fazer qualquer coisa não significa fazer algo de qualquer jeito. "Quando você está improvisando [...] dependendo da ideia que você tiver você vai para caminhos muito diferentes, não que exista juízo de valor, não que um caminho seja bom e outro seja ruim, acredito que isso faça muita diferença na dança que é apresentada de maneira improvisada" (TONTON, 2018).

A maneira como abordo a improvisação possui intensa influência das minhas vivências, o que afeta as propostas aqui elencadas dialogando com as reflexões geradas durante a escrita. Com base nas vivências obtidas em laboratórios de investigação durante aulas de improvisação, composição coreográfica e dança contemporânea e de conversas e estudos pertinentes a 
coreografia, nasceu em mim o interesse de compor coreografia pelo movimento improvisado. Esse é um procedimento que vem crescendo e se destacando cada vez mais no cenário da dança nos últimos anos, tanto no que diz respeito a pesquisa acadêmica quanto na construção de espetáculos.

As possibilidades geradas pela improvisação são infinitas. Dentre elas está seu uso como criação coreográfica. Na prática, a exploração de elementos imagéticos, sensoriais, motrizes e sua relação com as dinâmicas de tempo e construções espaciais geram uma gama de materiais a serem lapidados por meio de procedimentos de seleção e organização para que estes venham compor uma coreografia afetada pelas vivências dos laboratórios, diferenciando-se também da composição instantânea, em que o ponto principal é compor a cena no momento e não sendo apenas a reprodução de uma junção de movimentos elaborada previamente.

A maneira como muitos artistas da dança passaram a olhar a construção das obras que criavam foi transformada no período em que a improvisação conquistou notoriedade como estratégia de composição. "Nas últimas décadas temos o prazer de interagir com os processos de criação, de acompanhar o surgimento dessas metáforas complexas, pois, a fórmula de seguir um conteúdo programático chamado espetáculo de dança, já não é mais o único paradigma dominante" (LESTE, 2010, p. 78).

No desenvolvimento deste trabalho, entende-se que a coreografia sendo concebida a partir dos movimentos gerados pelas improvisações dos intérpretescriadores partindo de propostas de um coreógrafo(a), possibilita caminhos para uma construção que tem origem nos procedimentos vivenciados em laboratórios de investigação corporal, contribuindo para a ampliação das potencialidades dos intérpretescriadores enquanto improvisadores e para o fortalecimento do entendimento e reconhecimento dessa abordagem na criação de dança. . 


\section{CONFLUÊECIAS}

\section{3 - Danças urbanas: Breaking e Hip Hop Freestyle}

Nas danças urbanas, existem poucos pesquisadores que escrevem sobre seus estudos investigativos do movimento. No âmbito dessas danças, prevalece a cultura da oralidade e, assim, são compartilhados os conhecimentos. Para auxiliar na fundamentação dessa parte da pesquisa, foram coletados dados etnográficos em entrevistas, tendo por inspiração a etnografia como procedimento metodológico. "Os dados etnográficos fornecem as chaves do mundo representado ou vivido pelo artista" (FORTIN, 2009, p. 82).

O tipo de entrevista utilizada foi a semiestruturada, constituindo-se de um roteiro elaborado com sete perguntas, sendo este adaptado às questões que surgiram no decorrer dos diálogos. Das cinco entrevistas realizadas, uma foi gravada em áudio (mp3) e transcrita posteriormente; as demais tiveram as falas registradas em texto quando as perguntas foram sendo respondidas. "Mesmo quando o pesquisador efetua uma coleta de dados sobre a prática de outros artistas, é a partir de sua posição de artista que ele o faz, e isto pinta o processo da coleta e da análise" (FORTIN, 2009, p. 85).

A escolha dos entrevistados se deu por estes se relacionarem com as danças urbanas através da prática em treinos ${ }^{7}$, fazendo e/ou dando aulas, pesquisando e coreografando na área ou por meio da criação colaborativa com alguma outra dança. Todos têm hoje como local de atuação o Distrito Federal, residindo no Plano Piloto e na Região Administrativa de Taguatinga. Possuem entre 22 e 30 anos de idade e, no mínimo, 10 anos de experiência com a dança, fazendo parte de algum grupo como dançarino, dirigindo e/ou coreografando um grupo ou como dançarino independente.

Dentre os cinco participantes, Lucas Emanuel Rodrigues - Emanu, cursa Licenciatura em Dança (IFB) e Renato Fernandes é formado em dança pelo Europa Ballet St. Polten com especialização em Dança Contemporânea pelo Conselho de Dança de Viena - Áustria. Antônio Alves - TonTon possui graduação em Educação Física (UNB) e formação em Moda pelo IESB, Pedro Ivo - Bisturi, cursa graduação em Administração (UNB) e Samuel Paniago, cursa graduação em História também na UNB. Optei por apresentar os nomes dos entrevistados

\footnotetext{
${ }^{7}$ Segundo alguns dos entrevistados o momento de treinar está relacionado à execução mecânica do movimento, que se diferencia do ensaio, onde são aplicados os conhecimentos trabalhados durante o treino juntamente a outros elementos, como por exemplo a música
} 
seguidos de suas falas, por considerar relevante identificá-los, assim como ocorre com os autores abordados. Os artistas, ao concederem as informações, estavam cientes dessa escolha.

Cada entrevista quis reunir informações a respeito dos elementos que constituem as danças urbanas breaking e hip hop freestyle bem como sobre a relação dessas danças com o movimento improvisado e a criação de coreografia. Partindo das vivências dos artistas participantes e dos conhecimentos adquiridos por eles, busco estabelecer um diálogo no intuito de que as observações expostas auxiliem no entendimento de como ocorre a composição coreográfica nessas danças e quais aspectos abordados nesse processo convergem com o objetivo deste trabalho.

As danças urbanas breaking e hip hop freestyle foram selecionadas para esta pesquisa por eu já ter tido alguma proximidade com estas, em especial com o breaking, e perceber nessas danças fundamentos que se associam aos conceitos de improvisação e intérpretecriador. Outra questão que me chama a atenção é a recorrência com que práticas e corpos provenientes dessas danças se fazem presentes em pesquisas e composições coreográficas que muitas vezes são embasadas pelo pensamento contemporâneo em dança.

A dança breaking é um dos quatro elementos principais da cultura hip hop juntamente com o Rap, o Mc e o Grafitti. Representa a arte corporal e, por ser o primeiro estilo vinculado às danças urbanas, ou street dance, termo como é popularmente conhecida no mundo, tem um lugar de maior destaque entre as demais. Ao ter contato com dançarinos praticantes do breaking, denominados b-boys e b-girls, percebi que, durante os treinos, eles procuravam encontrar diferentes maneiras de se movimentar, que transcendessem a execução dos passos base:

O Breakin' foi a primeira técnica a se organizar no movimento Hip Hop, formatado entre os anos 70 e 80 . Tem como seus principais fundamentos: o top rock, movimentos usados para transições e início de sequências antecedendo à chegada ao chão; drop, movimentos usados para transitar níveis alto e baixo; foot works, movimentos de pés e pernas com o uso ou não das mãos, usando troca de bases constantes e o corpo paralelo ao solo; freeze, elemento que inicia, interrompe ou finaliza a performance do b-boy, pose; power moves, movimentos acrobáticos que utilizam apoios e eixos para realizar rotações, movimentos de dificuldade e velocidade. Ainda existe o up rock, que são movimentos com intuito de provocação, batalha e luta. (VIEIRA; BOM, 2015. p. 4).

O hip hop freestyle $e^{8}$ também é uma dança da cultura hip hop e seu surgimento se deu em função da música de mesmo nome, também conhecida como rap. Segundo o dançarino e pesquisador Henrique Bianchini (2016), "no final dos anos 80 o cenário era esse [...] a cultura deu origem ao estilo musical e esse por sua vez deu origem a uma forma de dança. A cultura é

\footnotetext{
${ }^{8}$ Para alguns artistas da dança o termo freestyle é considerado um estilo próprio de dançar, equivalente a uma "marca registrada". Compreendo e utilizo o termo no sentido de improviso, assim como os artistas das danças urbanas entrevistados afirmam em suas falas.
} 
hip hop, o estilo musical virou hip hop, estava sendo construído por tanto o que viria a ser chamado de hip hop dance". Esse termo hip hop dance não foi bem aceito pelos b-boys, os representantes originais da dança nessa cultura:

\begin{abstract}
Alguns personagens centrais da chamada hip hop dance, passaram a defender a inclusão do termo freestyle ao nome dessa dança. Na metade da década de 90 após o ressurgimento do breaking, Buddha Stretch, por exemplo, começou a tentar implantar essa ideia, hip hop freestyle seria um termo respeitoso e que faz juz ao que essa dança apresenta. (BIANCHINI, 2016).
\end{abstract}

Segundo Vieira e Bom (2015, p. 4), ofreestyle se baseia "não apenas no ritmo da música, mas também nas convenções vocais e instrumentais da música. Na sua origem os dançarinos misturavam os passos de todas as danças que sabiam e montavam sequências coreografadas para fazer performances em festas". Dado isso, justifica-se a expressão freestyle ser introduzida ao nome da dança, pois sua tradução significa improviso que, como veremos mais a frente, é um dos princípios mais importantes das danças urbanas.

Ao presenciar encontros entre dançarinos e professores de danças urbanas, me atentei a alguns aspectos que estavam presentes: a exploração do movimento pela improvisação, a música sempre como ferramenta indispensável na coreografia e a disponibilidade para com o outro ao treinar e para criar algo. "Todas as danças urbanas [...] surgem em contextos culturais sociais. Quando elas surgem nesses contextos, o foco não é na forma ou na mecânica ou na ideia, o foco é no social, na socialização da coisa, na diversão, você se envolver com pessoas" (TONTON, 2018).

Esses fatores aparecem no breaking e no hip hop freestyle, pois "as danças urbanas são improviso em essência, elas são uma resposta a um estímulo que você tem e a partir de um contexto cultural esse estímulo gerou em um grupo de pessoas uma resposta específica que é o que a gente acredita ser os fundamentos daquela dança" (TONTON, 2018). Considero que tais aspectos dialogam com o conceito de improvisação como composição coreográfica, apresentado aqui nessa pesquisa, como construção de experiências corpóreas na produção de dança. Percebo a presença dessas conexões também na fala do intérpretecriador Bisturi (2018):

\footnotetext{
Muitas das danças urbanas se originaram fora do ambiente de academia, [...] como o Breaking nas periferias do Bronx. Acredito que a improvisação está na essência das danças urbanas, visando mostrar cada vez mais um movimento novo, diferente e único e ao mesmo tempo compartilhar e passar algo dentro dessa vivência. Para mim, o uso do improviso é indissociável do contexto das danças urbanas, talvez por esse motivo tenham surgido mais e mais movimentações e ramificações das danças urbanas. (BISTURI, 2018).
}

Entendo que o pensamento contemporâneo em dança é abarcado pelas danças urbanas nos momentos em que favorece uma reflexão e contextualização conscientes a respeito das 
ações ocorridas em seu percurso e em relação à preparação, organização e produção de coreografia. Ao desenvolver o senso crítico de maneira sensível e auxiliar na propagação dos conhecimentos adquiridos através dessa abordagem, é evidenciada a necessidade de experienciar o movimento em diferentes âmbitos:

[...] o pensamento contemporâneo de dança é basicamente o que é indissociável das danças urbanas [...] o jeito que eu danço hip hop hoje não é o jeito que eles dançaram em 1980 por mais que lá seja a minha referência, eu não quero dançar que nem eles e nem pretendo dançar que nem eles mas, os meus olhos é a origem de onde começou e eu preciso estabelecer uma relação com aquilo. (TONTON,2018).

Nessa perspectiva, reconheço, em alguns elementos dessas danças, potenciais conexões que auxiliam no entendimento da improvisação como coreografia. Nos treinos, por exemplo, o dançarino efetiva sua prática não só pela repetição de um movimento até atingir a execução técnica desejada, mas também se coloca no lugar de investigar as sensações que a movimentação traz, interpretando como isso o afeta e, ao mesmo tempo, fazendo uma ligação com a música integrando conhecimentos e habilidades com o intuito de desenvolver uma dança mais orgânica:

O dançarino busca se movimentar construindo seu próprio estilo em cada performance. O "feeling" é a sensação em tempo real, influenciada pela música em grande parte das vezes; é uma forma individual e subjetiva, ligada a sensação de prazer, pela qual o dançarino interpreta e, por sua vez, se expressa através da dança ao ouvir a música, que o faz produzir determinados movimentos em determinados momentos da improvisação. (VIEIRA; BOM, 2015. p. 16).

Ao realizar as entrevistas, notei que, ao abordar as danças urbanas, os artistas apresentaram questões recorrentes em suas falas, principalmente sobre a musicalidade e a liberdade, fatores muito presentes no contexto do improviso nessas danças. Esses aspectos possuem grande relevância ao pensarmos na criação em dança, de coreografia, visando possibilitar experiências corpóreas que instigam uma reflexão sensível sobre seu fazer e seus desdobramentos.

\section{1 - Musicalidade e Liberdade}

As danças urbanas possuem uma relação intensa com a música, tanto que muitas delas se originaram em consequência das músicas tocadas em festas, locais onde surgiram também os chamados passos sociais. A forma mais comum de expressar essa relação se dá quando o dançarino busca combinar sua movimentação com a pulsação, o ritmo, a melodia, os fundamentos que compõem a música. Ao explorá-los, encontram-se caminhos que possibilitam uma cadência quase que natural, gerando um ambiente confortável: 
Quando os artistas optam por utilizar músicas em seus espetáculos de dança devem primeiramente se tornar público daquela obra. Saber ouvi la, percebê la com um "ouvido cego", receptivo, sem interpretações, sem pré definições, sem pré-conceitos. Apenas se banhar na massa de ondas sonoras, vibrações, não somente com o ouvido, mas com o corpo todo. Som é movimento, é vibração. (PASSOS, 2016, p. 34).

Para os dançarinos e coreógrafos em geral, a música se constitui como um elemento que, durante um longo período, foi considerado como o ponto de partida para criar dança. Ainda hoje, muitos artistas utilizam dessa proposição para iniciar seus processos coreográficos. Por meio dos dados apontados pelos entrevistados, fica visível que esse recurso é adotado entre os artistas das danças urbanas principalmente pelos princípios de seu contexto de origem terem sido preservados mesmo com as diversas fragmentações ocorridas dentro dessa linguagem:

[...] as danças urbanas, assim, aí é pretensioso da minha parte, mas eu acredito profundamente nisso, que nenhuma dança urbana surgiu sem previamente haver uma música, porque as danças urbanas, elas são cometidas no meio social e normalmente esses meios sociais possuem músicas que são as coisas que dão origem ao movimento. Então no caso das danças urbanas, contextualmente falando, elas estão completamente derivadas da música, de um sentimento que é gerado a partir daquelas músicas que eles ouvem naquela época. (TONTON, 2018).

Na relação da música com a dança, na maioria das técnicas existentes, "durante muito tempo, em um trabalho coreográfico, era praticamente exigido pelos paradigmas estéticos que a música fosse "visível" [...] há coreógrafos que começam com um trabalho musical, ouvemno, estudam a partitura até entender sua estrutura" (RENGEL et al, 2016, p.16). Sendo a musicalidade um fator intrínseco ao movimento, um ponto relevante nesse sentido, que pude perceber em minhas vivências, é o uso do silêncio nos laboratórios e práticas de investigação e na criação de coreografia.

Ao abordar o silêncio como escolha estética, é fundamental que haja a conscientização de que este também é parte da música. Essa percepção possibilita caminhos muito potentes a serem explorados, "tanto a música tocando e o dançarino silenciando, se imobilizando, quanto a dança se realizando antes da música, depois dela ou durante suas pausas preparando, continuando ou completando assim a vida sonora" (PASSOS, 2016, p. 31).

Quando questionados sobre dançar sem que houvesse música, alguns dos entrevistados relataram aspectos interessantes que auxiliam na reflexão acerca dos modos de compor dança, pois há diversas interpretações possíveis a respeito de informações semelhantes. Segundo o coreógrafo e pesquisador Paniago (2018), “o silêncio é um elemento dentro da música e é bom ser trabalhado dentro da dança. Uma dança no silêncio não fica presa às amarras que a música traz”. Para Bisturi (2018), “com ausência de música, o foco está nos movimentos, por isso busco sempre passar uma ideia, mensagem ou situação, partindo da minha movimentação. Porém, não me divirto tanto com a ausência da música". TonTon (2018) afirma que "não necessariamente, 
eu preciso dançar a dança hip hop na música hip hop, mas eu preciso desse estímulo sonoro, é algo para mim como pessoa, é imprescindível, não que eu não consiga ver isso nos outros, não que eu não consiga apreciar isso nos outros mas é porque para mim não funciona".

Tais pontos de vista me levaram a perceber que, na musicalidade e na improvisação em dança nos deparamos com elementos distintos que viabilizam acessar a criação de maneira significativa. Nos colocamos como observadores do processo enquanto sendo parte dele, buscamos refletir sobre o que nos motiva, a real importância que essa experiência possui e como os princípios constituintes da música e do movimento improvisado nos afetam. Lidamos a todo momento com a escolha:

A própria relação entre movimento e som pode vir a ser o tema de uma composição ou improvisação, onde o dançarino pode deixar se influenciar pela música (a reação aos fatores externos comandando a criação), pode negar ou não considerar a existência do estímulo sonoro (os impulsos interiores comandando a criação) ou pode conscientemente escolher momentos para reagir aos fatores externos ou agir por impulsos internos. (PASSOS, 2016, p. 32).

A liberdade é consequência desse poder de escolha, na dança "ela tem a ver com domínio de bases, de conceitos, de ideias, de estruturas que compõe aquela estética para que você possa determinar se você vai utilizar elas ou não, mas antes de você determinar isso você precisa saber, e aí você precisa ter essa habilidade de fazer escolhas" (TONTON, 2018). Essa abertura em relação ao desenvolvimento da composição coreográfica está também vinculada ao pensamento contemporâneo em dança e a construção de sentido a partir deste:

Criar livremente não significa poder fazer tudo e qualquer coisa a qualquer momento, em quaisquer circunstâncias e de qualquer maneira. Ser livre é uma condição estruturada e altamente seletiva, sempre vinculada a uma intencionalidade presente, embora talvez inconscientes, e a valores (individuais e sociais) de uma época. Ao se criar, define-se algo até então desconhecido, interligam-se aspectos múltiplos e às vezes divergentes entre si. Mas nada é feito ao acaso, as criações são orientadas pelas opções possíveis a um indivíduo em um determinado momento. (PASSOS, 2012, p. 80).

Considerando essa associação entre musicalidade, liberdade e improvisação, Paniago (2018) afirma utilizar “técnicas de diferentes linguagens da dança, tentando misturar estéticas. Muitas vezes saem movimentos que nunca tinha experimentado e, se gosto do que fiz, posso usá-los numa coreografia, geralmente escuto o começo da música para me familiarizar antes de começar a me movimentar". Percebo que essa fala apresenta elementos que se conectam ao entendimento de improvisação como coreografia, ainda que a construção de sentido esteja diretamente ligada à musicalidade:

Uso muito mais da improvisação do que de passos sociais (conhecidos por todos) dentro das minhas coreografias, mas não os excluo na hora de montar uma coreografia. Como a improvisação é algo treinado pela maioria dos dançarinos de danças urbanas, é comum usar e abusar dela para a criação de uma coreografia, além 
de deixar a coreografia com um aspecto muito mais fluido e natural, seguindo o que o corpo responde dentro da música. (PANIAGO, 2018).

Ao investigar de que maneira os movimentos se revelam tendo a música como estímulo principal, o artista afirma realizar ações que antes não havia vivenciado e que, ao dilatar esse parâmetro, a dança se apresenta de maneira orgânica. No ato de improvisar, o corpo também pode ser explorado através da percepção dos sentidos, da dinâmica topográfica, de uma estrutura de ações e, como consequência, das escolhas feitas produzir organizações no tempo e no espaço, constituindo uma composição coreográfica, assim como na prática relatada.

Criar em dança é uma prática que exige, além de conhecimentos e estratégias, sensibilidade, disponibilidade, dedicação e certa ousadia. "Normalmente o contexto do improviso é um pouco assustador, porque a liberdade é assustadora, as pessoas não são acostumadas a falar assim "vai lá dança, faz o que você quiser" e isso é meio assustador [...] é mais fácil você fazer escolhas dentro de uma determinada situação" (TONTON, 2018). A improvisação, inclusive nas danças urbanas, requer dos envolvidos algum desprendimento de suas convicções para que seja possível ir ao encontro de novos movimentos e a outras maneiras de dançar os já conhecidos.

Nesse sentido, a música e seus desdobramentos, os quais apresentam-se em vários momentos quase que inseparáveis da dança, tem na liberdade de escolha proporcionada pelo improviso caminhos para uma dança mais orgânica, instigando a busca pelo movimento consciente e viabilizando a construção de experiências motoras e sensoriais ligadas a reflexão sensível. "Em espetáculos de dança quase sempre vemos coreografias, composições elaboradas de dança e raramente as improvisações estão presentes como parte planejada do espetáculo [...] coreografia e improvisação podem ser equivalentes, o que decide o valor da criação é o seu sentido" (PASSOS, 2012, p. 81). 


\section{LIAMES}

\section{4 - Reflexões sobre a improvisação como coreografia}

As observações sobre o fazer da dança expostas nesse estudo visam evidenciar o entendimento da improvisação como coreografia. Para isso, aborda diferentes perspectivas pertinentes aos procedimentos relativos à composição coreográfica e o papel dos envolvidos em sua construção. "As noções de coreografia e coreógrafo nos últimos dez anos abrangem uma gama de processos e formas diversificados e refletem como cada um trabalha seu modo de olhar para o mundo" (MUNIZ, 2014, p. 187).

Os conhecimentos adquiridos ao longo da vida se conectam com os processos de criação e tem influência significativa na improvisação, tendo como foco o processo vivenciado e não um produto final. Ao tratar da criação de coreografia pela improvisação, estabelecendo também relações com o entendimento e as experiências dos pesquisadores entrevistados, são agregadas concepções que partem de suas próprias investigações do movimento, apresentando caminhos e estratégias imbuídas das práticas de diversos códigos que fazem parte de seu vocabulário.

O pesquisador e coreógrafo Emanu (2018) reconhece a importância da improvisação nos processos de criação coreográfica ao declarar: "Particularmente acredito que toda concepção de criação que tenho venha de impulsos de improviso. Não costumo utilizar os movimentos de forma metódica e sem o risco da escolha momentânea. Não existe para mim criação sem meu impulso criador de assumir o eu momentâneo. O risco de ser sendo". Tal proposta está interligada a sua visão de mundo, articulando questionamentos e reflexões.

Quando se fala em fazer coreografia, o pensamento mais comum que vem à mente é “quais movimentos posso fazer naquela música?”. Esse padrão é visto como o ponto inicial de um processo criativo em dança, pois, durante um longo período, foi sendo repetido e estimulado entre coreógrafos, bailarinos e professores. Acredito que a ligação existente entre música e dança seja muito intensa, porém não vejo uma como dependente da outra. Com as diversas transformações ocorridas sobre o conceito de dança, outras maneiras de pensá-la e fazê-la foram ganhando notoriedade entre os profissionais da área. Uma das questões mais exploradas até os dias de hoje é "quando se está dançando?":

A dança trabalha com todos os meios de construção de sentido, tais como a palavra, a imagem, a narrativa ou o gesto nele mesmo. O que dá o sentido, ou o que trabalha na dança o sentido, é a integração destes elementos. Por essa razão, o sentido está na própria dança, na imanência do sentido na dança dos corpos. (MUNIZ, 2014, p. 151). 
É recorrente ouvir nos espaços comuns da dança, artistas e pesquisadores falarem sobre como realizam seus trabalhos de preparação corporal e de elaboração e organização de composições coreográficas. Uma referência reconhecida neste meio é a de orientações sobre como proceder na sala de ensaio, um tipo de roteiro a ser seguido. Geralmente, ele é composto por aquecimento/alongamento, memorizar uma sequência de movimentos pela repetição, praticar a sequência com uma música. É neste último momento que a grande maioria considera estar dançando.

É importante ressaltar que "movimentos são atravessados por ideias que são permeadas por gestos que são perfuradas por pensamentos. Essa transposição é ininterrupta: a elaboração do pensamento se dá em movimento assim como o corpo em mobilidade está imbuído do pensar" (PURPER, 2018, p. 28). Portanto essa separação que é feita, levando em consideração o roteiro geralmente utilizado, tem seu valor se for adotada no contexto didático, visto que, de maneira efetiva, a preparação, o aquecimento e a execução do movimento são maneiras de dançar.

Quando aplicados no sentido de ensino-aprendizagem, os conceitos de teoria e de prática costumam ser abordados separadamente no intuito de facilitar o entendimento da função que cada um possui. O recurso do roteiro exemplificado acima se assemelha a essa estratégia. É preciso entender que o modo como são dadas as orientações influenciam na absorção das informações. Nos primeiros momentos dos processos de criação, acredito ser interessante efetuar essa fragmentação dos procedimentos, visando introduzir a práxis com maior clareza, ainda assim deve-se salientar que esses conhecimentos se dão de forma integrada.

O que motiva a concepção de uma coreografia pode estar vinculado não só a uma determinada canção, mas também a um tema com grande visibilidade no contexto social vivido, a uma obra literária ou cinematográfica, a uma experiência ocorrida no cotidiano, o que evidencia a correlação entre movimento e pensamento:

[...] as coreografias precisam ter um porquê de existir. Então às vezes você está sentindo alguma coisa, por qualquer motivo que seja, e aí você vai se colocar numa situação de improviso e pegar algumas partes desse seu improviso juntar e montar essa coreografia, ou às vezes você quer significar alguma coisa que você não necessariamente está sentindo naquele momento mais você sabe que existe esse contexto, e aí você vai pensar sobre e ver como as pessoas interpretam aquilo, tem uma preocupação entre a relação entre o que você faz e o que as pessoas veem, no outro lado da história você está mais preocupado com como você sente aquilo que você está sentindo e como você pode expressar aquilo do que necessariamente como as pessoas absorvem aquilo. (TONTON, 2018).

Por meio da improvisação a criação de coreografia pode deixar de ser centrada em um único indivíduo, - o coreógrafo -, considerado o detentor do conhecimento. O espaço para 
dialogar e explorar, oportuniza uma redescoberta dos participantes enquanto pesquisadores do movimento ao se afirmarem como intérpretescriadores. "A diversidade é um fator que gera no campo da dança um ambiente mais rico e complexo. A exploração dos limites de cada corpo e sua corporalidade é um desafio que a consciência do artista desenvolve para descobrir como se mover e inventar" (MUNIZ, 2014, p. 104).

Por meio do improviso é possível extrair o cerne de cada bailarino envolvido no processo, resgatando sua linguagem mais crua e real, um recurso que pode render frutos incríveis e revelar o melhor de cada um. Em meus processos coreográficos costumo deixar os bailarinos sentirem sua vibração inicial, desenvolvendo uma temática guiada no geral, a partir disso vou criando estímulos e direcionando para o que eu desejo como produto final. Pessoalmente, considero muito mais fácil começar a me mover a partir do improviso e daí seguir para a formatação do que pretendo com a coreografia. (FERNANDES, 2019).

Colocar-se como intérpretecriador para muitos bailarinos é um enorme desafio. Além de lidar com as próprias buscas na investigação do movimento, essa é uma posição que carrega grandes responsabilidades por exigir comprometimento com diferentes fases da construção da coreografia. Sendo a improvisação um campo com uma vasta diversidade de procedimentos, ela favorece o desenvolvimento de uma autonomia sensível e crítico reflexiva:

O corpo que improvisa é um corpo mais apto. Um corpo capaz de acompanhar o processo de mudanças constantes que ocorreram na dança; portanto, um corpo criativo, emancipado no processo de diversificação, abrindo a possibilidade de que criadores trabalhem com o dançarino improvisador sem negligenciar o papel criativo. (MUNIZ, 2004, p.76).

Inúmeros fatores podem levar alguém a criar pelo movimento improvisado. Para Paniago (2018), “[...] é a liberdade que se pode ter dentro de um improviso. Não tem uma barreira te impedindo de misturar estéticas completamente diferentes. Isso ajuda no processo de criação porque abre um leque de possibilidades infinitas dentro da dança”. Essa liberdade permeia os processos colaborativos, onde a relação hierárquica entre coreógrafo e bailarinos dá lugar a uma parceria, cada um dedica uma parte de si ao que é proposto:

Acredito que seja uma troca né, coreografia, eu acho que se eu já chegasse com a coreografia pronta, o que eu já tentei fazer, e o resultado é sempre o mesmo [...] eu chego lá e mudo exatamente tudo o que eu tinha montado porque as coisas que eu montei na minha cabeça não fazem sentido com as pessoas que estão na minha frente. Se fossem vários eus trabalhando faria completo sentido, mas como eu tenho pessoas diferentes com corpos diferentes na minha frente não faz sentido eu vir com uma coreografia pré estabelecida, [...] eu diria que o improviso é praticamente essencial para o que eu faço até para a coreografia. (TONTON, 2018).

A reflexão suscitada por TonTon estabelece vínculos com o processo colaborativo em dança também ao direcionar seu olhar para aquele com quem vai partilhar a experiência de dançar - o aluno - e ao considerar este como parte essencial da criação. É estar aberto para algo que não foi determinado e se dispor a usar isso como estímulo, ou seja, "ver potência de criação 
naquilo que é de cada um e que lhes é possível doar - sem julgamentos, sem excesso de expectativas, sem invalidações" (PURPER, 2018, p. 21).

É importante enfatizar que as trocas de conhecimentos e vivências que acontecem entre os envolvidos em processos de composição, assim como nos processos de cópia e reprodução, podem influenciar o entendimento destes acerca dos conceitos abordados. Conforme afirma Purper (2018, p. 16), “os procedimentos para desenvolver trabalhos de composição em dança partem do pressuposto de que o percurso de criação engendra o processo de ensinoaprendizagem, sendo que esse caminho está sempre permeado por uma atmosfera de pesquisa".

Segundo Fernandes (2019), “intérpretes com liberdade de improviso são provavelmente mais propensos ao bom uso do desenvolvimento coreográfico, quanto maior for a pesquisa de movimento, maior seu repertório será". Ao serem perguntados sobre o que percebem ser habitual em suas investigações pela improvisação, alguns entrevistados, ao abordarem seu papel como intérpretescriadores, trazem referências que dialogam com tal afirmação. Paniago (2018) revela: "me desconecto do mundo que conhecemos, meu foco vai todo para minha dança e a música que toca. Meu corpo e o som se tornam um só, numa simbiose saudável e que me deixa bem. Posso expandir minha mente ao máximo para atingir níveis de criatividade que achei não serem possíveis". Bisturi (2018) possui uma experiência semelhante: "me desligo do ambiente que estou e fico imerso a isso, as vezes sem técnica alguma, somente a movimentação e a ideia na cabeça. E não é necessariamente uma cena com início, meio e fim. Posso começar com uma coisa, mudar pra outra".

Identifico nesses relatos elementos significativos decorrentes da prática da improvisação na busca da ampliação de um vocabulário próprio, este que é um dos principais recursos a serem usados em função da criação de coreografia. "A improvisação possibilita novos modelos de configuração energética para gerar, organizar e perceber o movimento" (MUNIZ, 2014, p. 89). Nas falas apresentadas pelos intérpretescriadores, nota-se uma presença dilatada, conectada a sensações internas e externas, articulando habilidades distintas a partir das escolhas feitas.

A partir da confluência entre a pesquisa coreográfica atravessada por elementos presentes na improvisação abordada pelas danças urbanas e também como estratégia de criação imbuída de um pensar crítico reflexivo ao compor dança, enxergo, nessa pesquisa, o movimento improvisado como composição coreográfica. A necessidade de investigar o conceito de coreografia neste trabalho, não está atrelada à negação das demais ideias que existem a esse respeito, mas sim ao desejo de ampliar seu entendimento, ou seja, enxergar a coreografia como processo viabilizador de experiências corpóreas sensíveis, inclusive quando se tem por objetivo um produto coreográfico final. 


\section{CONSIDERAÇÕES FINAIS}

A coreografia é, na dança, a estrutura pela qual se visualizam os conceitos, fundamentos e elementos que atravessam o corpo. É através da interpretação desses caminhos e da expressão no próprio ser que a dança nasce, ganha formas e afetos. A realização de sequências de passos codificados é capaz de nos causar sensações intensas, todavia quando há a presença de um processo de pesquisa por trás da dança apresentada, com o aprofundamento consciente das camadas nos procedimentos investigados, a percepção pode alcançar estados viscerais.

A improvisação fornece caminhos que instigam a busca minuciosa do movimento, pelos sentidos dos órgãos internos, pelos estímulos sonoros e visuais, pela reflexão crítica e sensível sobre a dança e seus desdobramentos. A improvisação como coreografia perpassa esses conhecimentos propiciando a construção de sentido pela experiência corpórea não se limitando à execução de movimentos com fim nela mesma. Ter vivenciado processos criativos pelo movimento improvisado, que, em alguns casos, se constituíram como produto final, ocasionou mudanças significativas em minha relação com a dança.

Concretizar essa pesquisa me proporcionou relembrar momentos em que experienciei a improvisação na elaboração de tais composições, onde detalhes de diferentes acontecimentos se somaram e me auxiliaram na busca por conhecimentos que impulsionaram o desenvolvimento deste trabalho. Me vi enquanto intérpretecriadora, coreógrafa e, recentemente, professora e observo como cada uma dessas vivências seguem integradas na minha constante formação de artista docente pesquisadora, e os afetos decorrentes desse fazer ganhando forma, inspirando esse texto.

O estímulo primeiro para realizar essa pesquisa se deu em virtude da minha vontade de expandir conhecimentos sobre o principal tema abordado: a improvisação como coreografia. Para tal, procurei referências a respeito deste e me deparei com posicionamentos que se associam às minhas perspectivas, bem como com as relações existentes entre os elementos e fases que se atravessam em um processo de criação. Ao perceber na vertente das danças urbanas características relevantes que dialogam com o pensamento contemporâneo em dança e tendo em sua origem o dançarino como intérpretecriador, reconheço ser significativo vincular esses aspectos a esse estudo a partir do olhar dessa estética.

Por meio do caminho metodológico adotado neste estudo, identifiquei diversos olhares

que se agregam aos entendimentos propostos e também perspectivas que, por mais que se aproximem e se relacionem com o objetivo aqui apresentado, me fizeram perceber a relevância do percurso trilhado por diversos artistas, e que resultou nas diferentes concepções existentes a 
respeito da composição coreográfica. Com algumas das falas dos entrevistados, compreendi que alguns trabalhos desenvolvidos com as danças urbanas, utilizam, de certa forma, o conceito de improvisação como coreografia investigado nessa pesquisa, sendo assim transmitido nos variados espaços nos quais estes ocorrem.

Ciente de que essas escolhas são nutridas por uma rede de pesquisadores, professores, coreógrafos e intérpretescriadores que se propuseram e estiveram disponíveis para refletir sobre estratégias, organizações e práticas do movimento, considero que, ao apresentar diversas perspectivas que exploram a compreensão da criação de/em dança como construção de uma experiência corpórea, defendo e evidencio, aqui nesse trabalho, a improvisação como coreografia dialogando com o pensamento contemporâneo em dança. 


\section{REFERÊNCIAS}

AGAMBEN, Giorgio. O que é o contemporâneo? e outros ensaios. Chapecó: Argos, 2009. Traduzido por Vinícius Nicastro Honesko.

BIANCHINI, Henrique. O nome "Hip Hop Dance"?. 2016. Disponível em <https://www.youtube.com/watch?v=yhUvgpKE_DQ>. Acesso em: 24 de nov. de 2018.

BOLSANELlO, Débora Pereira. Em Pleno Corpo: Educação Somática, Movimento e Saúde. N. 2. Editora Juruá. Curitiba. 2010.

CALDAS, Paulo et al. Coreo|Grafia. Dança não é (só) coreografia. 10. ed. Joinville: Instituto Festival de Dança de Joinville, 2017.

DANTAS, Mônica Fagundes. Ancoradas no corpo, ancoradas na experiência: etnografia, autoetnografia e estudos em dança. Urdimento, v. 2, n. 27, p.168-183, UDESC, 2016.

ELIAS, Marina. Improvisação como possibilidade de reinvenção da dança e do dançarino. Pós: Belo Horizonte, v. 10, n. 5, p.173-182, 2015.

FERREIRA, Alexandre. Intérprete-criador na dança contemporânea: Um corpo polissêmico e co-autor. Anais do II Congresso Nacional de Pesquisadores em Dança - Anda. Comitê Produção de Discurso Crítico sobre Dança. Goiânia. Dança/FEF/UFG, 2012.

FORTIN, Sylvie. Contribuições possíveis da Etnografia e da Autoetnografia para a pesquisa na prática artística. Revista Cena 7 - periódico do Programa de Pós Graduação em Artes Cênicas - UFRGS, n. 7, p. 85-95, 2009. Traduzido por Helena Maria Mello.

LANGENDONCK, Rosana van. História da Dança. 2008. Disponível em <http://culturaecurriculo.fde.sp.gov.br/Administracao/Anexos/Documentos/42009101416453 3Linha\%20do\%20Tempo\%20-\%20Historia\%20da\%20Danca.pdf >. Acesso em: 14 de abr. de 2019.

LESTE, Thembi Rosa. Dança: Modos de estar princípios organizativos em dança contemporânea. Dissertação (Mestrado) - Curso de Dança, Faculdade de Dança, UFBA, Salvador, 2010.

MOOJEN, Alexandra de Castilhos; PURPER, Raquel. Estudos coreográficos no ensino superior de dança. Revista de C. Humanas, Viçosa, v., n. 14, p.121-129, 2014.

MORAES, Janaína Guimarães. Processos abertos e suas instâncias - Criador(es), cena, plateia e o escambau. TCC (Graduação) - Curso de Licenciatura em Dança, IFB, Brasília, 2014.

MUNIZ, Zilá Maria. Improvisação como processo de composição na dança contemporânea. Dissertação (Mestrado) - Curso de Teatro, Centro de Artes, UDESC, Florianópolis, 2004. 
MUNIZ, Zilá Maria. A Improvisação como um elemento transformador da função do coreógrafo na dança. Tese (Doutorado) - Curso de Teatro, Centro de Artes, UDESC, Florianópolis, 2014.

NEPOMUCENO, Cínthia. Processo Transcoreográfico: Uma alternativa metodológica para a docência artística na área de dança. Tese (Doutorado) - Curso de Arte, Instituto de Artes, UNB, Brasília, 2014.

PAIXÃO, Paulo. Coreografia: Gramática da dança. 2003. Disponível em: $<$ http://beta.idanca.net/coreografia-gramatica-da-danca/>. Acesso em: 05 ago. 2018.

PASSOS, Juliana Cunha. Rolf Gelewski e as inter-relações entre forma, espaço e tempo: uma proposta pedagógica de improvisação para processos criativos em dança. Dissertação (Mestrado) - Curso de Artes da Cena, Instituto de Artes, UNICAMP, Campinas, 2012.

PASSOS, Juliana Cunha. O processo de criação em dança e sua relação com elementos da arte visual e musical: uma proposta de utilização de métodos de improvisação de Rolf Gelewski. Tese (Doutorado) - Curso de Artes da Cena, Instituto de Artes, UNICAMP, Campinas, 2016.

PIZARRO, Diego. Corpo, Interdisciplinaridade e Contato Improvisação. II Seminário e Mostra Nacional de Dança-Teatro, 2010, Viçosa/MG. Coletânea Caminhos da Dança-Teatro no Brasil. Viçosa/MG: Departamento de Artes e Humanidades - Curso de Dança, 2010.

PORATH, Vancleia Pereira de Campos. Dançando com o peixe vermelho: Encontro entre o processo Viewpoints e a Improvisação estruturada de Anna Halprin na composição cênico-coreográfica. Dissertação (Mestrado) - Curso de Artes, UNB, Brasília, 2012.

PURPER, Raquel. Reorientando processos artísticoseducacionais em dança contemporânea: Possibilidades de transfazer-se em uma proposta poéticopolíticopedagógica. Tese (Doutorado) - Curso de Teatro, Centro de Artes, UDESC, Florianópolis, 2018.

RENGEL, Lenira Peral; SCHAFFNER, Carmem Paternostro; OLIVEIRA, Eduardo. Dança, corpo e contemporaneidade. Salvador: UFBA, 2016.

SANTINHO, Gabriela di Nonato Salvador; OLIVEIRA, Kamilla Mesquita. Improvisação em dança. Guarapuava: UNICENTRO, 2013.

SILVA, Lidiane Rodrigues Campêlo da. et al. Pesquisa documental: Alternativa investigativa na formação docente. IX Congresso Nacional de Educação - Educere. III Encontro Sul Brasileiro de Psicopedagogia. PUCPR, Paraná, p.4555-4566, 2009.

SILVA, Patrícia Chavarelli Vilela da; RAMOS., Jarbas Siqueira. A improvisação em dança como ato político. Rascunhos, Uberlândia, v. 2, n. 2, p.140-154, 2015.

VIEIRA, Flávia Pagani; BOM, Francine Costa de. Fatores intervenientes nas performances de improviso de dançarinos de hip hop na batalha de dança. TCC (Graduação) - Curso de Educação Física, UNESC, Criciúma, 2015. 


\section{ENTREVISTAS}

BISTURI, Pedro Ivo Saliba. Brasília, 14 set. 2018. Entrevista concedida a Gisele Moraes Pereira.

EMANU, Lucas Emanuel Rodrigues. Brasília, 03 dez. 2018. Entrevista concedida a Gisele Moraes Pereira

FERNANDES, Renato. Brasília, 09 jan. 2019. Entrevista concedida a Gisele Moraes Pereira.

PANIAGO, Samuel. Brasília, 14 set. 2018. Entrevista concedida a Gisele Moraes Pereira.

TONTON, Antônio Alves. Brasília, 21 nov. 2018. Entrevista concedida a Gisele Moraes Pereira 
ANEXOS 


\section{ANEXO A - Termo de Consentimento Livre e Esclarecido}

Você está sendo convidado a participar da pesquisa "Improvisação como Coreografia?", de responsabilidade de Gisele Moraes Pereira, aluna da Licenciatura em Dança do Instituto Federal de Brasília. 0 objetivo desta pesquisa é buscar elementos para compreender a coreografia como produção que nasce da construção de experiências corpóreas buscando favorecer e potencializar o movimento improvisado como coreografia. Assim, gostaria de consultá-lo(a) sobre seu interesse e disponibilidade de cooperar com a pesquisa.

Você receberá todos os esclarecimentos necessários antes, durante e após a finalização da pesquisa. Os dados provenientes de sua participação na pesquisa, tais como questionários, entrevistas, arquivos de áudio, ficarão sob a guarda da pesquisadora responsável pela pesquisa, podendo ser citados no trabalho, lhe identificando ou não. A coleta de dados será realizada por meio de gravação de áudio em mp3 e texto. É para estes procedimentos que você está sendo convidado a participar. Sua participação na pesquisa não implica em nenhum risco.

Sua participação é voluntária e livre de qualquer remuneração ou benefício. Você é livre para recusar-se a participar, retirar seu consentimento ou interromper sua participação a qualquer momento. A recusa em participar não irá acarretar qualquer penalidade. Se você tiver qualquer dúvida em relação à pesquisa, você pode me contatar através do telefone (61) 99177 5405 ou pelo e-mail gisl.mors@gmail.com.

Este documento foi elaborado em duas vias, uma ficará com a pesquisadora responsável pela pesquisa e a outra com o senhor(a).

Assinatura do (a) participante

Assinatura da pesquisadora

Brasília, de de 


\section{ANEXO B - Roteiro Entrevista Semiestruturada}

1.O que você entende por improvisação?

2.O que você entende por coreografia?

3. Qual a importância da improvisação nos processos de criação coreográfica?

4.O que te faz criar quando improvisa?

5.Discorra sobre o uso do improviso nas danças urbanas.

6.Qual a relação da música com a dança urbana?

7.Como é dançar sem música? 